\title{
PENINGKATAN MEMBANDINGKAN DUA PECAHAN MELALUI STRATEGI CALILANG PADA SISWA KELAS VI SD MUHAMMADIYAH 1 BABAT
}

\author{
Dymas Zahruddin Azmy \& Izza Eka Ningrum \\ Universitas Muhammdiyah Lamongan \\ diemas16@gmail.com,izzaeka@gmail.com
}

\begin{abstract}
This study aims to improve students' ability to understand fraction comparisons of sixth graders at SD Muhammadiyah 1 Babat by using the CALILANG strategy. This type of research is classroom action research. The subjects in this study were students of class VI SD Muhammadiyah 1 Babat, totaling 10 students. Data collection techniques were carried out by observation, test, and documentary techniques. The research instrument used an observation sheet and a written test. The data analysis technique uses the mean formula whose results are presented in a qualitative descriptive form.

Keywords : Fraction, Calilang, Observation, Research
\end{abstract}

\begin{abstract}
Abstrak: Penelitian ini bertujuan untuk meningkatkan kemampuan siswa dalam memahami perbandingan pecahan siswa kelas VI SD Muhammadiyah 1 Babat dengan menggunakan strategi CACILANG. Jenis penelitian ini adalah penelitian tindakan kelas. Subyek dalam penelitian ini adalah siswa kelas VI SD Muhammadiyah 1 Babat yang berjumlah 10 siswa. Teknik pengumpulan data dilakukan dengan teknik observasi, tes, dan dokumenter. Instrumen penelitian ini mengunakan lembar observasi dan tes tulis. Teknik analisis data ini meggunakan rumus rerata yang hasilnya disampaikan dalam bentuk deskriptif kualitatif.
\end{abstract}

Kata Kunci : Pecahan, Calilang, Observasi, Penelitihan

\section{PENDAHULUAN}

Matematika merupakan salah satu mata pelajaran yang diberikan kepada semua peserta didik mulai SD hingga SMA/SMK (Ningrum, 2018). Mapel ini dapat membekali siswa berpikir yang logis, sistematis, kreatif dan mampu bekerja sama.

FONDATIA : Jurnal Pendidikan Dasar

Volume 5, Nomor 2, September 2021; 220-241

https://ejournal.stitpn.ac.id/index.php/fondatia 
Selama ini matematika masih dipandang sebagai mapel yang susah dan kurang diminati. Banyak siswa juga cenderung takut dengan pelajaran ini. ${ }^{1}$

Dalam mapel ini, siswa diharuskan menghafal rumus serta mampu menghitung dengan berbagai cara. Pada pembelajaran matematika kompetensi dasar (KD) membandingkan pecahan, susah untuk dipahami oleh siswa kelas VI SD. Siswa merasa kesulitan bagaimana cara membandingkan pecahan.

Membandingkan pecahan berarti melihat dua bilangan pecahan dan menentukan mana bilangan yang lebih besar. Untuk membandingkan pecahan maka yang harus dilakukan, yaitu membuat kedua pecahan memiliki penyebut yang sama, lalu melihat pecahan mana yang memiliki pembilang yang lebih besar. Cara itu dapat mengetahui pecahan mana yang lebih besar. Bagian yang agak sulit yaitu mengubah pecahan agar memiliki bilangan penyebut yang sama.

Bilangan pecahan merupakan steppingstone yang sangat penting untuk mempelajari matematika ke tingkat yang lebih tinggi. Bilangan pecahan juga digunakan dalam kehidupan sehari - hari. Akan tetapi, masih banyak siswa yang masih kesulitan atau ridak bisa mengerjakan dengan bilangan pecahan tersebut. Kesulitan tersebut seringkali disebabkan oleh pemahaman konsep. Padahal, memahami bilangan pecahan adalah hal yang sangat di butuhkan untuk mempelajari aljabar, geometri, dan aspek matematika yang lain yang lebih tinggi.

Bilangan pecahan merupakan bentuk yang lain suatu bilangan pada ilmu matematika, dinyatakan menjadi a/b, a adalah pembilang, $b$ adalah penyebut dengan $\mathrm{a}, \mathrm{b}$ adalah bilangan bulat serta $\mathrm{b} \neq 0$.

Pada Bahasa Inggris bilangan ini disebut sebagai "fraction". Bilangan pecahan a/b sendiri dibaca seperti "a per b". Bilangan ini mempunyai beberapa jenis atau macam, yaitu pecahan biasa, campuran, desimal dan senilai.

\footnotetext{
${ }^{1}$ Sudjana, Nana. 1989. Dasar-dasar Proses Belajar Mengajar. Bandung: Sinar Baru.
} 


\section{METODE PENELITIAN}

Di dalam suatu penelitian diperlukan penggunaan bermacam-macam metode penelitian untuk mendapatkan data-data yang tepat, relevan, obyektif dan dapat dipertanggung jawabkan.

Metode penelitian berasal dari dua kata yaitu metode dan penelitian. Metode berasal dari kata methodos yang berarti cara dan penelitian berasal dari kata teliti yang mempunyai arti cara-cara akurat dan relevan. ${ }^{2}$

Pengertian metode menurut Prof. Dr. Winarno Surakhmad adalah suatu cara yang merupakan alat untuk mencapai tujuan. Penelitian dalam bahasa Inggris diartikan research. Research adalah suatu usaha untuk menemukan, mengembangkan dan menguji kebenaran suatu pengetahuan, dimana usaha-usaha yang dilakukan menggunakan metode - metode ilmiah artinya berusaha untuk mendapatkan sesuatu untuk mengisi kekosongan atau kekurangan-kekurangan. ${ }^{3}$

\section{A. Perencanaan}

Kegiatan yang dilakukan dalam tahap perencanaan adalah sebagai berikut:

\section{Refleksi awal.}

1. Peneliti bersama dengan teman sejawat mengidentifikasi permasalahan tentang membandingkan dua pecahan dengan penyebut yang berbeda pada siswa kelas VI prestasinya sangat rendah.

2. Peneliti dan teman sejawat merumuskan permasalahan secara operasional, relevan, dengan rumusan masalah penelitian.

3. Peneliti dan teman sejawat merumuskan hipotesis tindakan.

4. Menetapkan dan merumuskan rancangan tindakan yang meliputi :

a) Menetapkan desain pembelajaran

b) Menyusun rancangan strategi penyampaian dan pengelolaan pembelajaran.

c) Menyusun metode dan alat perekam data.

2 Sukmadinata, Nana Syaodih. 2004. Metode Penelitian Pendidikan. Bandung: PT. Remaja Rosdakarya.

${ }^{3}$ Hadi, Sutrisno. 1982. Metodologi Research, Jilid 1. Yogyakarta: YP. Fak. Psikologi UGM. 
d) Menyusun rencana pengolahan data.

\section{B. Tahap Pelaksanaan Tindakan dan Pengamatan}

\section{Siklus I}

\section{Rencana}

Pada tahap rencana perbaikan pembelajaran siklus I ini rencana kegiatan pembelajaran berdasarkan pada latar belakang timbulnya masalah yaitu guru tidak menggunakan cara mengalikan silang antara pembilang dan penyebut pecahan I dan pecahan ke II, hanya berpedoman pada buku teks yang ada, maka pada rencana perbaikan guru akan menggunakan cara menyamakan penyebut dulu baru membandingkan dua pecahan tersebut.

Untuk itu peneliti akan melakukan langkah-langkah perbaikan sebagai berikut :

- Menyusun skenario rencana perbaikan pembelajaran sesuai dengan masalah yang telah ditetapkan.

- Mempersiapkan Sumber, Alat dan media pembelajaran.

- Menyusun lembar observasi.

\section{Pelaksanaan}

Pada tahap pelaksanaan peneliti melaksanakan kegiatan pembelajaran di kelas yang sebenarnya sesuai dengan rencana yang telah ditetapkan. ${ }^{4}$

Dalam pelaksanaan perbaikan pembelajaran siklus I sebenarnya peneliti dibantu oleh teman sejawat yang bertugas mengamati dan mencatat data selama pelaksanaan perbaikan pembelajaran berlangsung.

Pelaksanaan perbaikan pembelajaran siklus I peneliti melaksanakan 2 prosedur pembelajaran yaitu prosedur umum dan prosedur khusus perbaikan pembelajaran.

${ }^{4}$ Surakhmad, Winarno. 1990. Metode Pengajaran Nasional. Bandung: Jemmars. 


\section{a. Prosedur Umum Perbaikan Pembelajaran Siklus I}

Pada siklus I prosedur umum perbaikan pembelajaran terdiri dari kegiatan awal, kegiatan inti dan kegiatan akhir.

Kegiatan Awal berlangsung 5 menit dengan kegiatan :

1) Guru memotivasi siswa dengan tanya jawab tentang perbandingan.

2) Menyampaikan tujuan pembelajaran.

Kegiatan Inti 55 menit dengan kegiatan:

1) Siswa memperhatikan penjelasan tentang membandingkan dua pecahan dengan penyebut yang berbeda.

2) Siswa dibimbing membandingkan dua pecahan melalui lembar kerja siswa.

3) Siswa mengerjakan soal

4) Siswa diberi kesempatan untuk bertanya.

5) Siswa bersama guru membuat kesimpulan.

Kegiatan Akhir 10 menit dengan kegiatan :

1) Guru memberi penguatan

2) Guru memberikan tes formatif

3) Guru memberikan tindak lanjut.

\section{b. Prosedur Khusus Perbaikan Pembelajaran Siklus I}

Sesuai dengan fokus pembelajaran dimana guru tidak menggunakan media apapun, maka pada pelaksanaan perbaikan pembelajaran siklus I guru menggunakan cara menyamakan penyebut kedua pecahan dengan menggunakan KPK, ternyata hasil evaluasi perbaikan pembelajaran meningkat. Standar keberhasilan klasikal baru mencapai $61 \%$

\section{Observasi}

Pada tahap pelaksanaan perbaikan pembelajaran, peneliti dibantu teman sejawat yang bertugas mengamatai proses pembelajaran. Berdasarkan catatan pengamat (teman sejawat) pada pelaksanaan perbaikan pembelajaran peneliti 
menggunakan cara yang panjang. Hal tersebut membuat siswa tampak lelah, siswa kurang aktif, minat siswa terhadap materi pembelajaran masih rendah, sehingga mengerjakan soal membutuhkan waktu yang lama dan tidak tuntas akibatnya standar keberhasilan individual baru mencapai 66,97.\%

\section{Refleksi}

Setelah kegiatan pelaksanaan dan observasi selesai dilaksanakan, peneliti melakukan refleksi. Dalam melakukan refleksi peneliti dibantu teman sejawat dan supervisor. Dari hasil refleksi peneliti menemukan kelemahan dan kekuatan dalam pelaksanaan perbaikan pembelajaran siklus I

Kelemahan dalam pelaksanaan perbaikan pembelajaran siklus I, guru kurang menanamkan konsep membandingkan dua pecahan yang praktis, masih dengan cara yang panjang dan kurang kongkrit sehingga minat siswa terhadap pembelajaran masih rendah.

Sedangkan kelebihan dalam pelaksanaan perbaikan pembelajaran, guru menggunakan langkah-langkah yang sistematis sehingga lebih menarik dan siswa mulai aktif dibanding sebelum diadakan perbaikan serta adanya peningkatan hasil standar keberhasilan perorangan mencapai 66,97.\% dan standar keberhasilan klasikal mencapai $63,64 \%$

\section{SIKLUS II}

\section{Rencana}

Pada tahap rencana perbaikan pembelajaran siklus II ini, kegiatan rencana perbaikan pembelajaran berdasar pada kelemahan pelaksanaan pembelajaran siklus I yaitu minat siswa masih rendah dan menggunakan beberapa langkah pengerjaan yang melelahkan. Pada rencana perbaikan pembelajaran siklus II guru akan memotivasi siswa dan mengaktifkan siswa dalam pembelajaran dengan menggunakan cara mengalikan silang antara pembilang dan penyebut dari dua pecahan, sehingga langkah-langkah pengerjaan yang digunakan lebih pendek dan praktis.

Untuk itu peneliti akan melakukan langkah-langkah perbaikan sebagai berikut 
- Menyusun skenario rencana perbaikan pembelajaran.

- Mempersiapkan media pembelajaran

○ Menyusun lembar observasi siklus II

\section{Pelaksanaan}

Pada tahap pelaksanaan perbaikan siklus II peneliti melaksanakan kegiatan pembelajaran di dalam kelas yang sebenarnya sesuai dengan rencana yang telah disusun.

Sama dengan siklus I pelaksanaan perbaikan pembelajaran peneliti melakukan dua prosedur yaitu prosedur umum perbaikan pembelajaran siklus II dan prosedur khusus perbaikan pembelajaran.

\section{a. Prosedur Umum Perbaikan Pembelajaran Siklus II}

Pada siklus II prosedur umum perbaikan pembelajaran terdiri dari kegiatan awal, kegiatan inti, dan kegiatan akhir.

1) Kegiatan Awal 5 menit

○ Guru memotivasi siswa

- Menyampaikan tujuan pembelajaran

○ Tanya jawab tentang perbandingan

○ Membentuk kelompok.

2) Kegiatan Inti 55 menit.

- Menunjukkan beberapa kartu bilangan pecahan sederhana yang akan digunakan sebagai contoh.

- Siswa memperdalam konsep membandingkan dua pecahan

○ Siswa mengerjakan LKS 1 secara kelompok.

○ Wakil kelompok menyampaikan hasil kelompok.

○ Kelompok yang lain menanggapi hasil presentasi kelompok temannya.

○ Siswa bersama guru membuat kesimpulan

- Siswa mengerjakan soal tes mandiri 
3) Kegiatan Akhir 10 menit

○ Guru memberi penguatan

- Guru memberikan pesan-pesan moral

- Pelajaran diakhiri.

\section{b. Prosedur Khusus Perbaikan Pembelajaran Siklus II}

Prosedur khusus pada siklus II dilakukan guru mengatasi kelemahan pada siklus I. berdasarkan masukan dari teman sejawat belum tercapainya tujuan perbaikan pembelajaran karena minat belajar siswa terhadap materi pembelajaran masih rendah .Pada siklus II prosedur pelaksanaan khusus dilaksanakan untuk meningkatkan minat belajar siswa dengan mengaktifkan siswa dalam bermain mengalikan silang. Ternyata siswa lebih bersemangat sehingga hasilnya cukup memuaskan dan tingkat standar keberhasilan pembelajaran Klasikal mencapai 76, $97 \%$

\section{Observasi}

Pada tahap pelaksanaan perbaikan pembelajaran di kelas yang sebenarnya peneliti dibantu teman sejawatyang bertugas mengamati proses belajar mengajar dan mencatat data selama kegiatan belajar mengajar berlangsung. Dari hasil pengamatan oleh teman sejawat ternyata siswa nampak bersemangat dan antusias dalam pembelajaran membandingkan dua pecahan dengan penyebut yang tidak sama dengan cara mengalikan silang antara penyebut dan pembilang dasi kedua pecahan tersebut.

\section{Refleksi}

Pada tahap ini peneliti dibantu oleh teman sejawat supervisor ternyata dari hasil refleksi peneliti menyimpulkan hasil perbaikan pembelajaran siklus II mencapai standar keberhasilan perorangan 76,15.\% dan standar keberhasilan klasikal mencapai $84,61 \%$, hal ini dapat dilihat dari hasil nilai evaluasi perbaikan pembelajaran siklus II.

\section{Tempat Penelitian}

Penelitian dilaksanakan di SD Muhammadiyah 1 Babat Kelas VI Semester I Tahun pelajaran 2021/2022 dengan jumlah siswa 10 anak. 


\section{HASIL DAN PEMBAHASAN}

Agar diperoleh data-data yang akurat, baik yang menyangkut konsep, langkah-langkah pembelajaran dan penerapannya, maka data yang sudah diperoleh perlu dianalisa dengan langkah-langkah sebagai berikut :

○ Mencatat data-data yang terkumpul.

o Melakukan penafsiran terhadap data-data yang sudah diperoleh.

○ Menyimpulkan apakah dalam pembelajaran terjadi peningkatan.

- Tahap tindak lanjut, merumuskan langkah-langkah perbaikan.

Analisa data dilakukan dengan :

1. Analisa Data Hasil Tes

Analisa data hasil tes dilakukan untuk mengetahui ketuntasan belajar individual maupun klasikal.

Ketuntasan belajar individual dihitung menggunakan rumus :

$$
\text { Kind }=\frac{\text { Jumlah skor yang diperoleh }}{\text { Skor maksimum }} \times 100 \%
$$

Ketuntasan belajar Klasikal dihitung menggunakan rumus :

$$
\text { Kelas }=\frac{\text { Jumlah siswa yang tuntas individual }}{\text { Jumlah seluruh siswa di kelas }} \times 100 \%
$$

Sebagai standar ketuntasan belajar siswa digunakan patokan yang ditetapkan Depdiknas, untuk ketuntasan individual sebesar $70 \%$ dan untuk ketuntasan belajar klasikal sebesar $85 \%$

2. Analisa Data Hasil Pengamatan

Data ini adalah data untuk mengetahui aktivitas siswa. Analisa data ini dilakukan dengan cara menghitung frekuensi dan presentase masing-masing aktivitas yang muncul selama kegiatan pembelajaran. 


\section{Data Angket Siswa}

Data angket siswa digunakan untuk mengetahui secara langsung dari siswa tentang proses pembelajaran operasi hitung membandingkan dua pecahan dengan penyebut yang tidak sama.

\section{Siklus I}

\section{a. Rencana Perbaikan Pembelajaran}

Rencana perbaikan pembelajaran siklus I dilaksanakan di kelas VI SD Muhammadiyah 1 Babat Kabupaten Lamongan. Materi yang diberikan adalah operasi hitung dengan pecahan Adapun hasil belajarnya adalah melakukan penjumlahan dan pengurangan pecahan Indikator perbaikan pembelajaran siklus I ini adalah. Membandingkan dua pecahan (termasuk yang tak sejenis) serta letaknya pada garis bilangan.

Sedangkan tujuan perbaikannya adalah Siswa dapat melakukan operasi hitung membandingkan dua pecahan dengan penyebut yang tidak sama ( pecahan tidak sejenis)

Dalam perencanaan perbaikan siklus I, peneliti melakukan tiga kegiatan yaitu :

(1) kegiatan awal selama 5 menit,

(2) kegiatan inti selama 55 menit, dan

(3) kegiatan akhir selama 10 menit.

Pada kegiatan awal penelitian Guru memotivasi siswa dengan tanya jawab tentang perbandingan, dan menyampaikan tujuan pembelajaran. Pada kegiatan inti Siswa memperhatikan penjelasan tentang membandingkan dua pecahan dengan penyebut yang berbeda, Siswa dibimbing membandingkan dua pecahan melalui lembar kerja siswa. Dan pada kegiatan akhir guru memberikan tes formatif.

\section{b. Pelaksanaan Perbaikan Pembelajaran}

Perbaikan pembelajaran siklus I dilaksanakan di kelas VI SD Muhammadiyah 1 Babat Kabupaten Lamongan dengan prosedur pelaksanaan sebagai berikut. Pada pembelajaran peneliti mengajukan pertanyaan tentang materi pelajaran yang lalu. 
Kemudian siswa mengerjakan LKS yang dibagikan guru. Kemudian guru menunjuk beberapa siswa untuk melakukan operasi hitung membandingkan dua pecahan yang tidak sejenis. Dari hasil pengamatan peneliti dan teman sejawat,siswa sudah dapat menyelesaikan soal dengan baik, untuk itu peneliti menganggap siswa sudah dapat melakukan operasi hitung membandingkan dua pecahan yang tidak sejenis. Dan untuk membuktikannya siswa disuruh mengerjakan soal buatan guru.

\section{c. Pengumpulan dan Pengolahan Data}

\section{Hasil Tes}

Berdasarkan hasil tes formatif pembelajaran awal tentang operasi hitung membandingkan dua pecahan sebanyak 10 soal siswa hanya mencapai keberhasilan $59,64 \%$.

Hasil tes siklus I dari 10 siswa yang menjawab benar semua tidak ada, siswa yang menjawab benar 8 soal sebanyak 1 siswa, siswa yang menjawab benar 7 soal sebanyak 3 siswa, siswa yang menjawab benar 6 soal sebanyak 1 siswa, siswa yang menjawab benar 5 soal sebanyak 2 siswa, dan siswa yang menjawab benar 2 soal sebanyak 3 siswa.

Tabel 2 Data Skor Hasil Tes Pembelajaran Siklus I

\begin{tabular}{|l|l|l|l|l|l|}
\hline \multirow{2}{*}{ No } & \multirow{2}{*}{ Nama Siswa } & Jml & Ketercapaian & \multicolumn{2}{|l|}{ Ketuntasan } \\
\cline { 5 - 7 } & & Skor & $\mathbf{\%}$ & Ya & Tidak \\
\hline 1 & Dedi Setiadi & 8 & 80 & V & \\
\hline 2 & Hendra Prasetya U & 7 & 70 & V & \\
\hline 3 & Jaka Lesmana & 6 & 60 & & V \\
\hline 4 & Murniwati & 7 & 70 & V & \\
\hline 5 & Mita Ayu Putri & 5 & 50 & & V \\
\hline 6 & M. Arif & 6 & 60 & & V \\
\hline 7 & Riris Lestari & 8 & 80 & V & \\
\hline 8 & Santi Nur Fitria & 2 & 20 & & V \\
\hline 9 & Sinta Dewi H & 7 & 70 & V & \\
\hline 10 & Uliyana & 5 & 50 & & V \\
\hline \multicolumn{2}{|l}{ Jumlah } & $\mathbf{6 1}$ & $\mathbf{6 1 , 0 0 \%}$ & $\mathbf{5}$ & $\mathbf{5}$ \\
\hline
\end{tabular}

Hasil Analisis

a. Ketuntasan belajar perorangan $=61 / 100 \times 100 \%=61 \%$ 
b. Ketuntasan belajar klasikal $=6 / 10 \times 100 \%=60 \%$

Kesimpulan :

Ketuntasan perorangan baru $61 \%$ belum $70 \%$

Ketuntasan Klasikal baru $60 \%$ belum $80 \%$

Hasil tes menunjukkan adanya peningkatan ketuntasan hasil belajar siswa jika dibandingkan sebelum berlangsungnya kegiatan PTK, yaitu dari 3 siswa menjadi 5 siswa. Dari 7 siswa yang mengikuti tes pada siklus I ini ternyata ada 5 siswa yang belum mencapai ketuntasan belajar.

Nilai tes siklus I hasilnya belum mencapai standar yang diharapkan sehingga perlu dilakukan perbaikan pada siklus II.

\section{Hasil Pengamatan}

Selama proses pembelajaran berlangsung, observasi dilakukan oleh satu orang pengamat (kolaborator) yang mengamatai aktivitas siswa dalam pembelajaran.

Dari hasil pengamatan kelas di atas dapat diperoleh rekapan data aktivitas siswa pada proses pembelajaran operasi hitung membandingkan dua pecahan yang tidak sejenis dengan cara menyamakan penyebut sebagaimana pada tabel berikut :

Tabel 3 Rekap Data Aktivitas Siswa dalam Pembelajaran Siklus I

\begin{tabular}{|l|l|l|l|}
\hline No & Aspek yang Diamati & Persentase & Keterangan \\
\hline 1 & Aktif dalam kegiatan pembelajaran & $76 \%$ & \\
2 & Melaksanakan kegiatan & $85 \%$ & \\
3 & Melakukan diskusi dalam kelompok & $61 \%$ & \\
4 & Mengemukakan pendapat dalam diskusi & $15 \%$ & \\
5 & Mengajukan pertanyaan & $7 \%$ & \\
6 & Menarik kesimpulan & $7 \%$ & \\
\hline
\end{tabular}

Dari hasil pengamatan di atas bahwa siswa mengemukakan pendapat, mengajukan pertanyaan sangat rendah dan tidak dapat mengambil kesimpulan.

\section{Data Angket Siswa}

Angket siswa setelah dikumpulkan dan direkap memperoleh data sebagai berikut: 
Tabel. 4 Angket Siswa Siklus I

\begin{tabular}{|c|c|c|c|c|c|c|c|c|c|}
\hline \multirow{3}{*}{ No } & \multirow{3}{*}{ Soal / Pernyataan } & \multicolumn{8}{|c|}{ Persentase Jawaban Siswa } \\
\hline & & \multicolumn{2}{|c|}{$\mathrm{Ya}$} & \multicolumn{2}{|c|}{ Cukup } & \multicolumn{2}{|c|}{ Kurang } & \multicolumn{2}{|c|}{ Tidak } \\
\hline & & $\mathrm{Jml}$ & $\%$ & $\mathrm{Jml}$ & $\%$ & $\mathrm{Jml}$ & $\%$ & $\mathrm{Jml}$ & $\%$ \\
\hline 1 & $\begin{array}{l}\text { Apakah pembelajaran yang telah } \\
\text { dilaksanakan oleh guru dapat } \\
\text { membantu meningkatkan kemampuan } \\
\text { siswa? }\end{array}$ & 4 & 40 & 3 & 30 & 3 & 30 & 0 & 0 \\
\hline 2 & $\begin{array}{l}\text { Apakah guru menyampaikan materi } \\
\text { pelajaran dengan jelas dan mudah } \\
\text { diterima? }\end{array}$ & 5 & 50 & 2 & 20 & 2 & 20 & 1 & 10 \\
\hline 3 & $\begin{array}{l}\text { Apakah penampilan guru } \\
\text { pembelajaran menyenangkan? }\end{array}$ & 6 & 60 & 2 & 20 & 1 & 10 & 1 & 10 \\
\hline 4 & $\begin{array}{l}\text { Apakah cara pembelajaran yang } \\
\text { disampaikan guru menarik dan } \\
\text { menyenangkan? }\end{array}$ & 6 & 60 & 1 & 10 & 2 & 20 & 1 & 10 \\
\hline 5 & $\begin{array}{l}\text { Apakah kamu mengalami kebingungan } \\
\text { dalam melaksanakan pembelajaran? }\end{array}$ & 5 & 50 & 4 & 40 & 1 & 10 & 0 & 0 \\
\hline 6 & $\begin{array}{l}\text { Apakah kamu mendapat bimbingan } \\
\text { dari guru saat proses pembelajaran } \\
\text { berlangsung? }\end{array}$ & 6 & 60 & 3 & 30 & 1 & 10 & 0 & 0 \\
\hline 7 & $\begin{array}{l}\text { Apakah kamu selalu melaksanakan } \\
\text { kegiatan pembelajaran dari awal sampai } \\
\text { selesai? }\end{array}$ & 7 & 70 & 1 & 10 & 0 & 0 & 0 & 0 \\
\hline 8 & $\begin{array}{l}\text { Apakah kegiatan pembelajaran yang } \\
\text { dilaksanakan membangkitkan motivasi } \\
\text { belajar? }\end{array}$ & 7 & 70 & 1 & 10 & 0 & 0 & 0 & 0 \\
\hline 9 & $\begin{array}{l}\text { Apakah kegiatan pembelajaran yang } \\
\text { dilaksanakan merupakan hal yang } \\
\text { menantang untuk dilaksanakan? }\end{array}$ & 6 & 60 & 1 & 10 & 2 & 20 & 0 & 0 \\
\hline 10 & $\begin{array}{l}\text { Apakah kegiatan pembelajaran yang } \\
\text { dilaksanakan merupakan hal yang baru } \\
\text { ? }\end{array}$ & 7 & 70 & 1 & 10 & 0 & 0 & 0 & 0 \\
\hline
\end{tabular}

Dari data angket siswa di atas dapat dikatakan bahwa proses pembelajaran operasi hitung membandingkan dua pecahan yang tidak sejenis ada kelemahan disamping ada hal-hal yang baik atau cukup baik. Kelemahan tersebut adalah :

- Kurang dapat meningkatkan kemampuan siswa. 
○ Kurang menarik atau menyenangkan.

- Tidak membangkitkan motivasi.

○ Membutuhkan waktu pengerjaan yang lama.

Dari beberapa kelemahan tersebut perlu perbaikan dan dapat sebagi pertimbangan didalam membuat perencanaan pada siklus II.

\section{d. Refleksi}

Pada perbaikan pembelajaran siklus I, materi yang diberikan adalah melakukan operasi hitung membandingkan dua pecahan yang tidak sejenis, sedangkan tujuan perbaikan adalah siswa dapat melakukan operasi hitung membandingkan dua pecahan yang tidak sejenis dengan cara menyamakan penyebut dari dua pecahan tersebut.

Berdasarkan hasil tes ditemukan bahwa 63,64\% dari jumlah siswa sudah dapat melakukan operasi hitung membandingkan dua pecahan yang tidak sejenis. Oleh karena itu perbaikan pembelajaran pada siklus I belum sepenuhnya berhasil dan perlu diadakan tindakan perbaikan berikutnya.

Menurut hasil diskusi dan pengamatan yang dilakukan oleh teman sejawat bahwa melakukan operasi hitung membandingkan dua pecahan yang tidak sejenis sudah ada beberapa kemajuan antara lain sebagian besar siswa sudah memahami konsep membandingkan dua pecahan, namun dalam pengerjaannya membutuhkan waktu yang lama sehingga peneliti dan teman sejawat sepakat perlu adanya langkahlangkah yang lebih singkat / pendek, agar pemahaman siswa lebih meningkat dan dapat menggunakan waktu yang lebih singkat, sebab selama mengerjakan soal siswa selalu kekurangan waktu.

Dari hal tersebut di atas peneliti dan teman sejawat berdiskusi akan menggunakan cara mengalikan antara pembilang pecahan pertama dengan penyebut pecahan ke- dua dan mengalikan penyebut pecahan pertama dan pembilang pecahan kedua. 


\section{Siklus II}

\section{a. Rencana Perbaikan Pembelajaran}

Rencana perbaikan pembelajaran siklus II dilaksanakan di kelas VI SD Muhammadiyah 1 Babat Kabupaten Lamongan. Materi yang diberikan adalah operasi hitung dengan pecahan. Adapun hasil belajarnya adalah melakukan penjumlahan dan pengurangan pecahan Indikator perbaikan pembelajaran siklus II ini adalah. Membandingkan dua pecahan (termasuk yang tak sejenis) serta letaknya pada garis bilangan.

.Sedangkan tujuan perbaikannya adalah Siswa dapat melakukan operasi hitung membandingkan dua pecahan dengan penyebut yang tidak sama ( pecahan tidak sejenis)

Dalam perencanaan perbaikan siklus II, peneliti melakukan tiga kegiatan yaitu :

(1) kegiatan awal selama 5 menit,

(2) kegiatan inti selama 55 menit, dan

(3) kegiatan akhir selama 10 menit.

Pada kegiatan awal penelitian Guru memotivasi siswa dengan tanya jawab tentang perbandingan, dan menyampaikan tujuan pembelajaran. Pada kegiatan inti Siswa memperhatikan penjelasan tentang membandingkan dua pecahan dengan penyebut yang berbeda, Siswa dibimbing membandingkan dua pecahan melalui lembar kerja siswa. Dan pada kegiatan akhir guru memberikan tes formatif tentang membandingkan dua pecahan yang tidak sejenis.

\section{b. Pelaksanaan Perbaikan Pembelajaran}

Perbaikan pembelajaran siklus II dilaksanakan di kelas VI $\quad$ SD Muhammadiyah 1 Babat Kabupaten Lamongan. Hal ini dilakukan berdasarkan hasil tes formatif pada siklus I masih belum memenuhi target keberhasilan pembelajaran. Oleh karena itu peneliti menggunakan cara dengan mengalikan pembilang pecahan pertama dan penyebut pecahan ke dua dan sebaliknya.

Pada awal pembelajaran, peneliti mengingatkan konsep pada siklus I, karena siswa sudah paham namun belum berhasil sepenuhnya. 
Kemudian Peneliti menjelaskan bahwa pembilang pecahan pertama didapat dari mengalikan silang antara pembilang pecahan pertama kali penyebut pecahan kedua, dan sebaliknya pembilang pecahan ke dua di dapat dari mengalikan pembilang pecahan kedua dengan penyebut pecahan pertama. Sehingga jika sudah diketahui hasil perkaliannya tinggal membandingkan pembilangnya saja tanpa harus melihat penyebutnya.

Kemudian siswa melanjutkan LKS yang lain yang dibagikan guru. Guru menunjuk beberapa siswa maju untuk menuliskan hasil pekerjaannya. Dari kegiatan tersebut terlihat siswa sudah dapat melakukan operasi membandingkan dua pecahan yang tidak sejenis dengan waktu yang lebih cepat. Oleh karena itu peneliti dan teman sejawat menganggap anak-anak sudah dapat melakukan operasi hitung membandingkan dua pecahan yang tidak sejenis. Untuk membuktikannya anak-anak sudah dapat melakukan operasi hitung membandingkan dua pecahan yang tidak sejenis dengan melihat tes akhir.

\section{c. Pengumpulan dan Pengolahan Data}

\section{Hasil Tes}

Berdasarkan hasil tes formatif pembelajaran siklus I tentang operasi hitung membandingkan dua pecahan sebanyak 10 soal siswa hanya mencapai keberhasilan $63,64 \%$.

Hasil tes siklus II dari 10 siswa yang menjawab benar semua ada 5 siswa, siswa yang menjawab benar 9 soal sebanyak 2 siswa, siswa yang menjawab benar 8 soal sebanyak 1 siswa, siswa yang menjawab benar 7 soal sebanyak 1 siswa, dan siswa yang menjawab benar 5 soal sebanyak 1 siswa.

Tabel 6 Data Skor Hasil Tes Siklus II

\begin{tabular}{|l|l|l|l|l|l|}
\hline \multirow{2}{*}{ No } & \multirow{2}{*}{ Nama Siswa } & Jml & Ketercapaian & \multicolumn{3}{|l|}{ Ketuntasan } \\
\cline { 5 - 7 } & & Skor & $\mathbf{\%}$ & Ya & Tidak \\
\hline 1 & Dedi Setiadi & 10 & 100 & V & \\
\hline 2 & Hendra Prasetya U & 8 & 80 & V & \\
\hline 3 & Jaka Lesmana & 7 & 70 & V & \\
\hline 4 & Murniwati & 9 & 90 & V & \\
\hline 5 & Mita Ayu Putri & 5 & 50 & & V \\
\hline
\end{tabular}




\begin{tabular}{|l|l|l|l|l|l|}
\hline 6 & M. Arif & 7 & 70 & V & \\
\hline 7 & Riris Lestari & 10 & 100 & V & \\
\hline 8 & Santi Nur Fitria & 7 & 70 & V & \\
\hline 9 & Sinta Dewi H & 9 & 90 & V & \\
\hline 10 & Uliyana & 8 & 80 & V & \\
\hline \multicolumn{2}{|l|}{ Jumlah } & $\mathbf{8 0}$ & $\mathbf{8 0} \%$ & $\mathbf{9}$ & $\mathbf{1}$ \\
\hline
\end{tabular}

Hasil Analisis

a. Ketuntasan belajar perorangan $=80 / 100 \times 100 \%=80 \%$

b. Ketuntasan belajar klasikal $=8 / 10 \times 100 \%=80 \%$

Kesimpulan :

Ketuntasan perorangan sudah $80 \%$ sudah melebihi $70 \%$

Ketuntasan Klasikal baru 80 \% sudah melebihi $80 \%$

Hasil tes menunjukkan adanya peningkatan ketuntasan hasil belajar siswa jika dibandingkan sebelum berlangsungnya kegiatan perbaikan siklus I, yaitu dari 5 siswa menjadi 9 siswa. Dari 10 siswa yang mengikuti tes pada siklus II ini ternyata ada 1 siswa yang belum mencapai ketuntasan belajar.

Nilai tes siklus II hasilnya sudah mencapai standar yang diharapkan sehingga tidak perlu dilakukan perbaikan pada siklus III.

\section{Hasil Pengamatan}

Selama proses pembelajaran berlangsung, observasi dilakukan oleh satu orang pengamat (kolaborator) yang mengamati aktivitas siswa dalam pembelajaran.

Dari hasil pengamatan kelas di atas dapat diperoleh rekapan data aktivitas siswa pada proses pembelajaran operasi hitung membandingkan dua pecahan yang tidak sejenis dengan cara menyamakan penyebut sebagaimana pada tabel berikut :

Tabel 7 Rekap Data Aktivitas Siswa dalam Pembelajaran

\begin{tabular}{|l|l|l|l|}
\hline No & Aspek yang Diamati & Persentase & Keterangan \\
\hline 1 & Aktif dalam kegiatan pembelajaran & $77 \%$ & \\
2 & Melaksanakan kegiatan & $92 \%$ & \\
3 & Melakukan diskusi dalam kelompok & $77 \%$ & \\
4 & Mengemukakan pendapat dalam diskusi & $66 \%$ & \\
\hline
\end{tabular}




\begin{tabular}{|l|l|l|l|}
\hline 5 & Mengajukan pertanyaan & $15 \%$ & \\
6 & Menarik kesimpulan & $69 \%$ & \\
\hline
\end{tabular}

Dari hasil pengamatan di atas bahwa siswa sudah ada yang dapat mengemukakan pendapat, dan dapat mengambil kesimpulan.namun masih sulit mengajukan pertanyaan

\section{Data Angket Siswa}

Angket siswa setelah dikumpulkan dan direkap memperoleh data sebagai berikut:

Tabel. 8 Angket Siswa Siklus II

\begin{tabular}{|c|c|c|c|c|c|c|c|c|c|}
\hline \multirow{3}{*}{ No } & \multirow{3}{*}{ Soal / Pernyataan } & \multicolumn{8}{|c|}{ Persentase Jawaban Siswa } \\
\hline & & \multicolumn{2}{|l|}{$\mathrm{Ya}$} & \multicolumn{2}{|c|}{ Cukup } & \multicolumn{2}{|c|}{ Kurang } & \multicolumn{2}{|c|}{ Tidak } \\
\hline & & $\mathrm{Jml}$ & $\%$ & Jml & $\%$ & Jml & $\%$ & $\mathrm{Jml}$ & $\%$ \\
\hline 1 & $\begin{array}{l}\text { Apakah pembelajaran yang telah } \\
\text { dilaksanakan oleh guru dapat } \\
\text { membantu meningkatkan kemampuan } \\
\text { siswa? }\end{array}$ & 5 & 50 & 3 & 30 & 1 & 10 & 1 & 10 \\
\hline 2 & $\begin{array}{l}\text { Apakah guru menyampaikan materi } \\
\text { pelajaran dengan jelas dan mudah } \\
\text { diterima? }\end{array}$ & 6 & 60 & 1 & 10 & 2 & 20 & 1 & 10 \\
\hline 3 & $\begin{array}{l}\text { Apakah penampilan guru dalam } \\
\text { pembelajaran menyenangkan? }\end{array}$ & 6 & 60 & 2 & 20 & 1 & 10 & 1 & 10 \\
\hline 4 & $\begin{array}{l}\text { Apakah cara pembelajaran yang } \\
\text { disampaikan guru menarik dan } \\
\text { menyenangkan? }\end{array}$ & 7 & 70 & 1 & 10 & 1 & 10 & 1 & 10 \\
\hline 5 & $\begin{array}{l}\text { Apakah kamu mengalami kebingungan } \\
\text { dalam melaksanakan pembelajaran? }\end{array}$ & 6 & 60 & 2 & 20 & 1 & 10 & 1 & 10 \\
\hline 6 & $\begin{array}{l}\text { Apakah kamu mendapat bimbingan } \\
\text { dari guru saat proses pembelajaran } \\
\text { berlangsung? }\end{array}$ & 6 & 60 & 2 & 20 & 2 & 20 & 0 & 0 \\
\hline 7 & $\begin{array}{l}\text { Apakah kamu selalu melaksanakan } \\
\text { kegiatan pembelajaran dari awal sampai } \\
\text { selesai? }\end{array}$ & 5 & 50 & 4 & 40 & 1 & 10 & 0 & 0 \\
\hline 8 & $\begin{array}{l}\text { Apakah kegiatan pembelajaran yang } \\
\text { dilaksanakan membangkitkan motivasi } \\
\text { belajar? }\end{array}$ & 6 & 60 & 3 & 30 & 1 & 10 & 0 & 0 \\
\hline 9 & $\begin{array}{l}\text { Apakah kegiatan pembelajaran yang } \\
\text { dilaksanakan merupakan hal yang } \\
\text { menantang untuk dilaksanakan? }\end{array}$ & 5 & 50 & 5 & 50 & 0 & 0 & 0 & 0 \\
\hline
\end{tabular}




\begin{tabular}{|l|l|l|l|l|l|l|l|l|l|}
\hline 10 & $\begin{array}{l}\text { Apakah kegiatan pembelajaran yang } \\
\text { dilaksanakan merupakan hal yang baru } \\
?\end{array}$ & 6 & 60 & 4 & 40 & 0 & 0 & 0 & 0 \\
\hline
\end{tabular}

Dari data angket siswa di atas dapat dikatakan bahwa proses pembelajaran operasi hitung membandingkan dua pecahan yang tidak sejenis ada ada beberapa kelebihan antara lain :

- Dapat meningkatkan kemampuan siswa.

- Materi jelas dan mudah diterima

- Cukup menarik atau menyenangkan.

- Dapat membangkitkan motivasi..

- Membutuhkan waktu pengerjaan lebih cepat

Dari beberapa kelebihan tersebut maka dalam membandingkan dua pecahan yang tidak sejenis dapat digunakan cara dengan mengalikan silang antara pembilang dan penyebut dari dua pecahan tersebut.

\section{d. Refleksi}

Pada proses pembelajaran siklus II diperoleh data tentang beberapa kelebihan yang selanjutnya perlu dilakukan tindak lanjut diantaranya siswa lebih :

1. aktif dalam pembelajaran

2. mampu melaksanakan kegiatan

3. mampu menarik kesimpulan

4. berani mengemukakan pendapat

5. berminat dalam proses pembelajaran.

\section{B. Pembahasan}

1. Siklus I

Pembelajaran dalam siklus I adalah pembelajaran dalam upaya membantu siswa agar mereka dapat dengan mudah melakukan operasi hitung membandingkan dua pecahan yang tidak sejenis. Metode yang digunakan tanya jawab, tugas dan diskusi. Langkah-langkah yang digunakan adalah: 
- Mencari KPK dari dua pecahan yang dibandingkan.

- Menentukan penyebut yang sama.

- Mencari pembilang setelah penyebutnya sama.

- Membandingkan dua pembilang yang penyebutnya sudah sama.

- Mencari nama lain pecahan awal dengan pecahan yang baru.

- Membandingkan dua pecahan awal.

Hal ini dirasakan perlu karena pada pembelajaran sebelumnya siswa menggunakan cara dengan garis bilangan yang menjadikan anak senang tapi sampai pada bilangan tertentu, dengan bilangan yang lebih besar siswa merasa sangat sulit.

Dengan menggunakan langkah-langkah pada siklus I pemahaman siswa tentang operasi hitung membandingkan dua pecahan yang tidak sejenis memberikan kemajuan hasil yaitu standar ketuntasan perorangan mencapai $61 \%$ dan standar ketuntasan klasikal mencapai $60 \%$. Namun hasil tersebut belum memenuhi syarat minimal standar keberhasilan pembelajaran yaitu standar perorangan $70 \%$ dan standar keberhasilan klasikal $80 \%$. Oleh karena itu diadakan pembelajaran ulang dengan cara lain.

\section{Siklus II}

Perbaikan pembelajaran pada siklus II adalah pembelajaran dalam upaya membantu siswa agar mereka dapat dengan mudah melakukan operasi hitung membandingkan dua pecahan yang tidak sejenis

Metode yang digunakan tanya jawab, tugas dan diskusi. Langkah-langkah yang digunakan adalah:

- Mencari Pembilang pecahan pertama dengan cara pengalikannya dengan penyebut pecahan ke dua

- Mencarai pembilang pecahan ke-dua dengan cara mengalikannya dengan penyebut bilangan pertama.

- Membandingkan pembilang pecahan pertama dan pecahan ke-dua dengan memberi tanda $"<,=$, $>$ ". 
○ Membandingkan pecahan awal dengan tanda " $<,=,>$ "

Dalam kegiatan pembelajaran, setiap siswa terlihat aktif dan mendapat giliran untuk mengerjakan soal ke depan sehingga memberi hasil yang maksimal. Dengan mengalikan pembilang pecahan pertama dan penyebut pecahan ke-dua dan sebaliknya tentang membandingkan dua pecahan yang tidak sejenis memberikan hasil yang positif yaitu standar ketuntasan belajar perseorangan mencapai $80 \%$ berarti diatas $70 \%$ dan mencapai standar ketuntasan belajar klasikal $80 \%$ berarti sama dengan $80 \%$. Hal ini berarti ketuntasan perseorangan dan ketuntasan klasikal telah tercapai. Dengan demikian perbaikan pembelajaran pada siklus II dikatakan berhasil dan tidak perlu adanya perbaikan lagi. Sedangkan siswa yang belum berhasil menguasai materi perlu penanganan secara khusus.

\section{KESIMPULAN}

Dengan kegiatan pembelajaran operasi hitung membandingkan dua pecahan yang tidak sejenis dengan cara menyamakan penyebut dari dua pecahan memberikan hasil ketuntasan perseorangan $61 \%$ dan ketuntasan belajar klasikal $60 \%$. Pada siklus II peneliti melakukan pembelajaran operasi hitung membandingkan dua pecahan yang tidak sejenis dengan cara mengalikan silang ( Calilang) antara pembilang pecahan pertama dan penyebut pecahan ke-dua dan dengan mengalikan pembilang pecahan ke-dua dan penyebut pecahan pertama memberikan hasil ketuntasan belajar perseorangan $80 \%$ dan ketuntasan belajar klasikal $80 \%$.

\section{DAFTAR PUSTAKA}

Hadi, Sutrisno. 1982. Metodologi Research, Jilid 1. Yogyakarta: YP. Fak. Psikologi UGM. Khasanah, L. A. I. U., \& Subroto, W. T. (2018, April). THE DEVELOPMENT OF SCIENTIFIC BASED-INTEGRATED LEARNING TOOLS TYPE SHARED IN IMPROVE FOURTH GRADE STUDENT ELEMENTARY SCHOOL. In PROCEEDING CONFERENCE (p. 238).

Kharisma, A. I. (2020). PENGARUH PENGGUNAAN ALAT PERAGA GATOTKACA TERBANG TERHADAP HASIL BELAJAR 
MATEMATIKA PADA SISWA KELAS III SEKOLAH DASAR. Jurnal Review Pendidikan dan Pengajaran, 3(1), 16-23.

Kharisma, A. I. (2021). TEACHER'S EXPLAINING SKILLS IN THEMATIC LEARNING IN THE THIRD GRADE OF ELEMENTARY SCHOOL. Journal Of Educational Experts (JEE), 4(1), 25-36.

Lee, W.R. 1985. Language Teaching Games and Contests. London: Oxfortd University Press.

Melvin, L. Siberman. 2004. Aktif Learning, 101 Cara Belajar Siswa Aktif. Bandung: Nusamedia dan Nuansa.

MZ, A. S. A., Rusijono, R., \& Suryanti, S. (2021). Pengembangan dan Validasi Perangkat Pembelajaran Berbasis Problem Based Learning untuk Meningkatkan Keterampilan Berpikir Kreatif Siswa Sekolah Dasar. Jurnal Basicedu, 5(4), 2685-2690.

MZ, A. S. A. (2021). Pengaruh Penggunaan Media Gambar Seri terhadap Kemampuan Menulis Karangan Narasi Siswa Kelas V MI Muhammadiyah 1 Payaman. BINTANG, 3(1), 142-152.

Ningrum, I. E., \& Suparman, S. (2018, February). Analisis kebutuhan bahan ajar matematika berpendekatan kontekstual. In Prosiding Seminar Nasional Pendidikan Matematika Etnomatnesia.

Ningrum, I. E. (2018). Development Of Students Worksheet Mathematics Based On Problem Based Learning (PBL).

Rismawanda, R., \& Khasanah, L. A. I. U. (2021). Penerapan Metode Kooperatif pada Kompetensi Afektif dan Kongnitif Siswa Kelas IV MI Muhammadiyah 1 Sukodadi. MANAZHIM, 3(2), 253-262.

Sudjana, Nana. 1989. Dasar-dasar Proses Belajar Mengajar. Bandung: Sinar Baru.

Sukmadinata, Nana Syaodih. 2004. Metode Penelitian Pendidikan. Bandung: PT. Remaja Rosdakarya.

Surakhmad, Winarno. 1990. Metode Pengajaran Nasional. Bandung: Jemmars.

Weed, Gretchen, E. 1971. Using Games in Teaching Children. ELEC Bulletin

No. 32. Winter. Tokyo. Japan 